\title{
A Re-Examination of Near-Bankruptcy Investment Incentives
}

\author{
Barry E. Adler $\dagger$
}

The traditional justification for American corporate bankruptcy law is that bankruptcy's stay of individual creditor collection keeps the wolves at bay. Without bankruptcy, the story goes, creditors might fail to negotiate for united action and in their attempts to claim limited assets dismember an insolvent but viable firm. Anticipation and conduct of this race, moreover, would require creditors to expend resources unnecessarily. Accordingly, the accepted wisdom is that bankruptcy's collective proceeding protects the "common pool" of debtor assets for the aggregate benefit of creditors and consequently saves creditors the expense of strategic positioning.

An important component of this exegesis has been that bankruptcy law must protect firms from creditors not only after the onset of bankruptcy but also immediately before it. Thus, in many instances, a firm can recapture transfers to creditors if made while the firm is insolvent and within the ninety-day period prior to the firm's bankruptcy. These recapturable transfers are called voidable preferences. In the leading volume on modern bankruptcy theory, Thomas Jackson explains that voidable preference law "is essentially a transitional rule designed to prevent individual creditors from opting out of [bankruptcy's] collective proceeding once that event becomes likely. It is part of the attempt to ameliorate the effects of a common pool problem that justifies a collective proceeding in the first place."

On close analysis, however, preference law may not serve the purpose given in this standard justification. Preference law as guardian of the common pool is a notion based on a view of the firm as a static pool of assets that exists independently of the

$\dagger$ Professor of Law, University of Virginia. I thank Paul Mahoney and Alan Schwartz for helpful comments on model design and presentation. I thank Clay Gillette, Jody Kraus, Saul Levmore, Paul Mahoney, John McCoid, Bob Rasmussen, Randy Picker, Alan Schwartz, Bob Scott, David Skeel, George Triantis, Steven Walt, and participants in a George Mason University workshop for helpful comments on an earlier draft. I also thank Lorie Almon and Fred Polli for excellent research assistance.

1 Thomas H. Jackson, The Logic and Limits of Bankruptcy Law 125 (Harvard, 1986). 
preference rules themselves. In this Article, I challenge the static-pool assumption and examine the effects of preference law on dynamic asset pools. I argue that preference law may in fact diminish rather than protect assets available to a troubled firm. Because many-perhaps most-insolvent firms would be most valuable if liquidated, such diminution of a firm's assets may serve investors' collective interest.

Part I explores more thoroughly than existing scholarship the limitations of voidable preference law as protector of a distressed firm's assets. This Part concludes that there may be few circumstances in which the conventional wisdom about preference rules is theoretically sound. Current preference rules, which require creditors to return the value of transfers, but carry no penalty for violation, cannot provide comprehensive protection for a debtor firm's assets unless each creditor's collection action would be costly or would destroy a significant portion of a debtor firm's value. These conditions may be uncommon. Indeed, the latter condition is least likely where there are many creditors, each with too small a stake to justify the expense of coordination, the very circumstances that make bankruptcy useful. Moreover, even if a creditor's collection would be costly and would in isolation destroy firm value, the creditor may have little reason to refrain from collection because it would retain its collection if other creditors refrained, and because it would be unlikely to benefit much by refraining if other creditors collected. Thus, there are many circumstances in which creditors are likely to engage in a spirited race to an insolvent debtor's assets, voidable preference law notwithstanding.

Congress could strengthen the preference rules by permitting a creditor to prohibit collection by others before a race to assets begins. Congress could also impose penalties for violation of the rules. But any such strengthening could inefficiently raise the cost of finance because creditors would anticipate the impossibility or expense of collection even under circumstances in which they believed collection would not present a threat to the common pool. The preference rules, therefore, may not be too weak. They may serve some purpose other than to prevent collection.

Part II proposes an alternative purpose for voidable preference rules: the mitigation of overinvestment by insolvent firms. Managers of a firm in financial distress have a strong incentive to gamble with the firm's assets. Where managers are shareholders in the firm they manage, part of a gamble's appeal is the chance to salvage the shareholders'- "equity's"-interest in the 
firm. Such a gamble may be profitable ex ante for managers or equity, but not for investors collectively. For an insolvent firm, continuation itself may be of negative net present value and may, therefore, constitute a risky investment that equity and creditors would not have agreed to sanction ex ante were it possible to contract for all contingencies. Bankruptcy's voidable preference law discourages negative-net-present-value investment by negating eve-of-bankruptcy pledges of collateral for antecedent debt and by prohibiting the enforcement of promises to allow eve-ofbankruptcy collection of new loans before existing debt becomes due. Negation of these pledges and promises effectively raises a distressed firm's cost of capital and discourages unduly risky investment. This analysis uniquely demonstrates a solution to the puzzle of why preference law should void a creditor's eve-ofbankruptcy improvement of priority, which cannot result in dismemberment. Thus, as compared to the static-asset approach, this dynamic view offers a richer explanation of voidable preference law as part of a hypothetical investors' bargain.

Part III notes the limitation inherent in the overinvestment problem as a justification for voidable preference law. Preference rules tend to discourage investment generally, not merely in negative-net-present-value projects. There are circumstances in which a firm could finance positive-net-present-value projects only by offering existing collateral for antecedent debt or by allowing holders of new obligations to collect before existing debt becomes due. In these circumstances, the preference rules prevent investment that all investors would favor.

Part IV compares the over- and underinvestment problems that preference rules mitigate and exacerbate, respectively. Preference law provides efficient incentives for most firms only if the prospect of unduly risky investment is greater than the prospect of forgone profitable investment. This condition may well be satisfied. First, preference law is significant only to a firm that is insolvent and thus has likely failed to perform according to its investors' initial expectations. As a result, when preference law matters, the risk of overinvestment inherent in a firm's decision to continue may be a greater problem than the risk of a firm's inability to pursue a valuable project. Second, assuming the existence of an underinvestment problem, preference law may do little to exacerbate it. With or without preference law, each creditor may have a counterproductive incentive to free ride on another's financing of a new and valuable project, creating an underinvestment problem to which preference law may add little. 
Consequently, the overinvestment problem may generally justify voidable preference rules regardless of the underinvestment risk. And, as a result, statutory exceptions to avoidance, such as for collection on a fully secured loan or in the ordinary course of business, may not be justified.

Thus, though preference law may be flawed in its details and is fundamentally flawed in its immutability-because investors in some firms may be predominantly concerned with eve-of-bankruptcy underinvestment-Congress may have arrived at essentially correct rules for voiding preferential transfers. Congress may not have understood the effect of these rules, but the rules' benefits may explain their survival.

\section{Preservation of a Static Pool}

However destructive a race to an insolvent firm's assets, ${ }^{2}$ voidable preference law will not dissuade an individual creditor from collecting unless the collection process is costly or the creditor believes its action will destroy some nontrivial portion of the firm's value. If a creditor knows it can, at little cost, collect from assets not significantly related to other assets, the creditor will collect and, in the worst case for the creditor, a bankruptcy trustee will demand return of the collected amount to a pool, by hypothesis virtually undiminished by the creditor's own action, in which the creditor will then share ratably. In the best case for the creditor, the firm will remain out of bankruptcy for the statutory ninety-day preference period, ${ }^{3}$ and the creditor will receive full repayment while other creditors receive only partial repayment.

In fact, however, an individual creditor may have to expend nontrivial resources to collect and may significantly diminish the debtor's going-concern value. A creditor might not collect if collection is expensive or if the creditor believes preference law will force it to return its collection and share in a pool of assets de-

2 It is by no means certain that a race to assets is inefficient. As Tom Jackson notes, the elimination of a race to assets may carry its own costs such as the elimination of creditor monitors who might otherwise prevent management misbehavior. Jackson, The Logic and Limits of Bankruptcy Law at 18 (cited in note 1). For the sake of argument, I assume in this Part that a race to assets is inefficient.

3 When an insider of the debtor receives or receives benefit from the preferential transfer, the preference period is one year. See 11 USC \& 547(b)(4)(B) (1988). And the trustee may reclaim from the insider the value of voidable transfers made within the oneyear period. See 11 USCA $\S 550(a)$, (c) (West 1993 and Supp 1995). This refinement, however, is not significant to the analysis. 
valued by the creditor's thwarted action. For this reason, one cannot say as a matter of theory that preference law has no deterrent effect on collection.

Yet the voidable preference rules may provide a creditor little incentive to refrain even under realistic assumptions of costly collection and potential value destruction. While a refraining creditor of an insolvent firm saves collection costs, those costs may not be large compared to the potential individual benefit of collection in full. And no individual creditor that contemplates collection gains any other benefit from refraining unless other creditors also refrain. By hypothesis, coordination among creditors is prohibitively expensive; otherwise, bankruptcy law would be unnecessary. ${ }^{4}$ Ironically, then, the same collective-action problem that creates the need for bankruptcy law may be seen to impede the effectiveness of preference rules as part of that law. ${ }^{5}$

An example based on a simple model illustrates the limitations of voidable preference law as a deterrent to collection. Imagine that a firm possesses three discrete integrated assets worth $\$ 40$ as a set but worth $\$ 10$ each if any piece is even temporarily removed from the set. The firm is subject to claims of five identical creditors, each holding a $\$ 10$ obligation. Each creditor receives periodic information about the firm and knows at $t_{0}$ of the firm's assets and the other creditors. But no creditor has information about collection efforts by other creditors between periodic reports. Each creditor has an opportunity to attempt or refrain from collection at $t_{0}$. If four or more creditors attempt to collect at $t_{0}$, the firm will enter bankruptcy at $t_{0}$ and preference law will require each collecting creditor to return the amount collected. If three or fewer creditors collect at $t_{0}$, the firm will remain out of bankruptcy for the voidable preference period, but will be subject to bankruptcy at $t_{1}{ }^{6}$ In bankruptcy, each unpaid creditor will receive a ratable share of any returned or uncollected asset.

Thus, ignoring bankruptcy costs, if every creditor awaits a collective disposition of the firm's assets, no collection effort will destroy firm value and each creditor will receive $\$ 8 .^{7}$ If one to

4 For a description of coordination difficulty among creditors, see, for example, Maxwell L. Stearns, The Misguided Renaissance of Social Choice, 103 Yale L J 1219, 1239 n 75 (1994) (describing cycling).

s See Jackson, The Logic and Limits of Bankruptcy Law at 7-19 (cited in note 1) (describing bankruptcy as a solution to a collective-action problem).

I I relax this often unrealistic assumption below. See text accompanying notes 32-38.

7 That is: $\$ 40 / 5$ creditors. 
three creditors collect, each collecting creditor will receive an asset worth $\$ 10$, while each noncollecting creditor will receive $\$ 10(3-c) /(5-c)$, where $c$ is the number of collecting creditors. If more than three creditors attempt to collect, a bankruptcy will occur within the preference period, creditors will return the assets collected, and each creditor will receive $\$ 6$. $^{8}$

Given these conditions, and ignoring collection costs, the weakly dominant strategy for each creditor is to collect. ${ }^{9}$ To see why, compare the payoffs for refraining with the payoffs for attempting collection from the perspective of a single creditor. If the creditor refrains and all other creditors refrain, the creditor will receive a payoff of $\$ 8$. Yet collection would have yielded $\$ 10$. If the creditor refrains and one or two creditors collect, the refraining creditor will receive at most $\$ 5 .^{10}$ Again, collection would have yielded $\$ 10$. If the creditor refrains and three creditors collect, the creditor will receive nothing, as no assets will remain for anyone who refrains. Here, attempted collection would have triggered bankruptcy and yielded $\$ 6 .^{11}$ If the creditor refrains and four creditors attempt to collect, there will be bankruptcy and the creditor will receive $\$ 6$, the same amount it would have received had it attempted collection. Thus, as Table 1 illustrates, for all but one combination of strategies a creditor will maximize its payoff by attempting to collect. In the one exception, the creditor will do no worse by attempting to collect. Each creditor, then, will attempt to collect. Under these conditions, therefore, preference law has no deterrent effect.

"Collect" does not remain a weakly dominant strategy once the model includes the costs of collection, however. If the cost of an individual creditor's attempt to collect is positive, the creditor will do worse by attempting to collect than it will by refraining if the other four creditors attempt to collect. That is, if the creditor refrains while the four other creditors attempt to collect, the other four will induce a bankruptcy at $t_{0}$ and thus a $\$ 6$ return per

8 That is: $\$ 30 / 5$ creditors.

9 A strategy is weakly dominant if it is a player's best response to any strategies that other players might pick, in the sense that whatever strategies the others pick, her payoff is no smaller than with any other strategy and is greater in some strategy combination. See Eric Rasmusen, Games and Information: An Introduction to Game Theory 31 (Blackwell, 1989).

${ }^{10}$ This will be the payoff to each refraining creditor if only one creditor collects: $\$ 10(3-1) / 4$ creditors. Where two creditors collect, the payoff to the refrainers is $\$ 3.33$ : $\$ 10(3-2) / 3$ creditors.

11 That is: $\$ 30 / 5$ creditors. 


\section{TABLE 1: Collect or Refrain vs. Others Collecting (No Collection Cost)}

\begin{tabular}{c||c|c|c|c|c||}
\multicolumn{1}{c}{} & \multicolumn{1}{c}{0} & 1 & 2 & 3 & 4 \\
\cline { 2 - 6 } Collect & 10 & 10 & 10 & 6 & 6 \\
\cline { 2 - 6 } Refrain & 8 & 5 & 3.33 & 0 & 6 \\
\hline
\end{tabular}

creditor, including the creditor that does not attempt to collect. If the creditor attempts to collect along with the other four creditors, the creditor will receive $\$ 6$ less its collection cost.

Without preference law, "collect" is a dominant strategy ${ }^{12}$ given a cost of attempted collection that is less than the amount by which individual collection can exceed distribution under a collective proceeding, or $\$ 2$ in this example. To see this, note that if a collection attempt costs less than $\$ 2$, a creditor that collects a $\$ 10$ asset will gain more than the $\$ 8$ maximum distribution from a collective proceeding if two or fewer other creditors also collect. If three or four of the other creditors attempt to collect, a creditor that attempts to collect will expect to receive $3 / 4$ or $3 / 5$ of $\$ 10$, respectively, less the collection-attempt expense, while a creditor that refrains will receive $\$ 0 .{ }^{13}$

Thus, although preference law does not produce a dominant strategy equilibrium where there are positive collection costs, the law does eliminate a dominant strategy equilibrium at which each creditor attempts to collect. One might characterize this effect as a possible deterrent.

It is easy to overstate the possibility of deterrence, however. Collection expense may be as trivial as the cost of a letter or

12 A strategy is dominant if it is a player's strictly best response to any strategies the other players might pick, in the sense that whatever strategies they pick, her payoff is highest with the strategy in question. See Rasmusen, Games and Information at 28 (cited in note 9).

${ }^{13}$ Without preference law, which forces a return of collections in the event of bankruptcy, if four creditors attempt to collect, three of the four will obtain one of the three $\$ 10$ assets while the other will be left empty handed. If all five creditors attempt to collect, three of the five will obtain one of the three $\$ 10$ assets while the other two will be left empty handed. 
phone call demanding payment. This is because an insolvent firm's managers, who want to keep their jobs and, if they are loyal to shareholders (or are shareholders themselves), want to extend equity's option on the firm's assets, ${ }^{14}$ will probably not have the firm file for bankruptcy in the face of such a demand. Instead, the managers might well comply with the demand so the firm can save the expense of a creditor's collection proceeding. ${ }^{15}$ Such compliance, moreover, could prevent the publicity of litigation and the consequent rash of collection attempts by creditors with a contractual right to accelerate amounts due on their own loans if the firm fails to make timely payment on another creditor's loan. ${ }^{16}$ The possibility of voluntary payment makes realistic the prospect of trivial collection costs. Creditors might collect because the potential gain from collection-payment in full-is much larger than the gain from refraining-saved collection costs. ${ }^{17}$

Even under an assumption of significant collection expense, one can overstate preference law's deterrent effect. Add to the above collect-refrain game a $\$ 1$ collection-attempt cost. Continue to assume that a collective proceeding is itself costless. The payoff to an individual creditor from "collect" is $\$ 9$ if two or fewer others collect, ${ }^{18}$ and $\$ 5$ if three or four others attempt to collect. ${ }^{19}$ The payoff from "refrain" is $\$ 8$ if no one collects, ${ }^{20} \$ 5$ if one creditor collects, ${ }^{21} \$ 3.33$ if two creditors collect, ${ }^{22} \$ 0$ if three creditors collect, ${ }^{23}$ and $\$ 6$ if four creditors attempt to collect. ${ }^{24}$ As shown in Table 2, "collect" is not a dominant or a

${ }^{14}$ For a seminal article analogizing equity's interest to an option on a firm's assets, see Fischer Black and Myron Scholes, The Pricing of Options and Corporate Liabilities, 81 J Pol Economy 637 (1973).

${ }^{15}$ For further discussion, see note 33 and accompanying text.

16 That a payment may be voluntary, and not the consequence of public litigation, makes realistic the assumption in this model that creditors do not each observe the others' collection attempts.

${ }_{17}$ Compare Jean Hampton, Hobbes and the Social Contract Tradition 156-57 (Cambridge, 1986) (describing how games seemingly with no certain solution may resolve when players sacrifice a portion of a large potential gain to avoid losing the entire gain). But see Jody S. Kraus, The Limits of Hobbesian Contractarianism 118-19 (Cambridge, 1993) (questioning Hampton's assumptions).

18 Each collecting creditor receives a $\$ 10$ asset and incurs a $\$ 1$ collection expense.

19 Each collecting creditor returns the value of any collected asset, receives a $\$ 6$ ratable distribution, and incurs a $\$ 1$ collection expense.

${ }^{20}$ That is: $\$ 40 / 5$ creditors.

21 That is: $\$ 10(3-1) / 4$ creditors.

22 That is: $\$ 10(3-2) / 3$ creditors.

${ }^{23}$ The three collecting creditors keep all of the firm's assets.

24 Each collecting creditor returns the value of any collected asset. Each creditor then 
weakly dominant strategy because each creditor will maximize its payoff by refraining when the other four creditors attempt to collect. But "refrain" also is not a dominant or weakly dominant strategy because, except when four creditors attempt to collect, each creditor maximizes its payoff by attempting to collect.

\section{TABLE 2: Collect or Refrain vs. Others Collecting (With a Collection Cost of \$1)}

$\begin{array}{lllll}0 & 1 & 2 & 3 & 4\end{array}$

\begin{tabular}{l||c|c|c|c|c||}
\hline \multirow{4}{*}{ Collect } & 9 & 9 & 9 & 5 & 5 \\
\cline { 2 - 5 } Refrain & 8 & 5 & 3.33 & 0 & 6 \\
\hline
\end{tabular}

This game does have a pure-strategy equilibrium..$^{25}$ If four creditors attempt to collect and one refrains, no single creditor would have profited from taking the alternative action given the other players' actions. If one of the collecting creditors had instead refrained, that creditor would have received $\$ 0$ instead of the $\$ 5$ payoff that each collecting creditor gains when four attempt to collect. If the one refraining creditor had instead attempted to collect, that creditor would have gained $\$ 5$ instead of the $\$ 6$ a single refraining creditor gains. Thus, "four collect" is a pure-strategy equilibrium.

A mixed-strategy equilibrium also exists. ${ }^{26}$ If each creditor uses a randomization device that leads it to attempt collection just less than 96 percent of the time, no creditor has an incentive to defect from the common device. ${ }^{27}$ In equilibrium, there is then

receives $\$ 30 / 5$ creditors.

${ }^{25}$ A player employs a pure strategy when she follows a rule that tells her with certainty what action to choose. Rasmusen, Games and Information at 70 (cited in note 9). In a pure-strategy equilibrium, no player can profit from a change in action given the actions of the other players in that equilibrium. Id at 32-34.

${ }^{26}$ According to the standard definition, a player employs a mixed strategy when she uses a randomization device-such as a coin flip or a roll of dice-to determine her action. Id at 70. In a mixed-strategy equilibrium, no player can profit from a change in randomization device given the randomization devices of the other players in that equilibrium. Id at 32-34.

${ }_{27}$ This assumes the creditors are risk neutral. The expected payoff in equilibrium is 
about a 98 percent probability that at least four creditors will attempt to collect, ${ }^{28}$ and only a minuscule probability that no creditor will collect. ${ }^{29}$

Inasmuch as neither the pure- nor the mixed-strategy equilibrium results from dominant strategies, one may be able to infer little from either. These equilibria, however, may be illustrative of strong collection incentives. Imagine constraints on the decisions of some but not all creditors. Assume, for example, that factors not described in this model compel one of the five creditors to refrain. Such restraint, if known, will induce the other creditors to collect, given that "four collect" is an equilibrium. Assume instead that four of the creditors are influenced by unmodeled considerations known to the fifth creditor, such that the fifth creditor is led to believe that each of the other four will attempt collection with, say, 95 percent probability. The fifth creditor will attempt to collect. This is certain, given that the mixed-strategy equilibrium occurs when each creditor attempts collection with just less than 96 percent probability. That is, if each creditor believes the probability that each other creditor will attempt collection is just less than 96 percent, each creditor will

about $\$ 5.04$, the expected net payoff to a creditor from either attempting to collect or refraining where the probability that any one of the other four creditors will attempt collection is just less than 96 percent. That is, each creditor will be indifferent to collecting or refraining where the expected payoff to either action is the same. The expected payoff to any creditor from attempting to collect or refraining will be the same for probability $p$ such that, as $c$ ranges from 0 to $n, \sum \pi_{c}(c)(n ! /(c !(n-c) !)) p^{c}(1-p)^{n \cdot c}=\sum \pi_{R}(c)(n ! /$ $(c !(n-c) !)) p^{c}(1-p)^{n c}$, where $n$ is the number of other creditors, $c$ is the number of others that attempt collection, $\pi_{C}$ is the payoff from attempting collection given $c, \pi_{R}$ is the payoff from refraining given $c$, and $p$ is the probability that any one of the other creditors will attempt collection. Taking the values of $\pi_{c}$ and $\pi_{R}$ from Table 2 , this reduces to the polynomial equation $1+12 p-8 p^{2}-4 p^{3}-2 p^{4}=0$. One of the roots of that equation, $\mathrm{p} \approx .9557$, satisfies the condition of a probability, $0 \leq p \leq 1$. Thus, for this example, as $c$ ranges from 0 to $n, \sum \pi_{c}(c)(n ! /(c !(n-c) !)) p^{c}(1-p)^{n e} \approx \sum \pi_{R}(c)(n ! /(c !(n-c) !)) p^{c}(1-p)^{n \cdot c} \approx \$ 5.04$, where $p$ $=.9557$. For a full description of the model on which this example is based, see note 31 .

${ }^{28}$ The probability that at least four creditors will collect is given by $5 p^{4}(1-p)+p^{5}$, which is about .98 when $p=.9557$. This is derived from the binomial distribution formula described in note 27.

29 The probability that no creditor will collect is $(.0443)^{5}$, with .0443 the probability that any one creditor will refrain and 5 the number of creditors. One could change the probability that each creditor will refrain in equilibrium by adding creditors to the example. As the number of creditors increases relative to the size of the asset pool, collection attempts comprise a smaller portion of the randomization device in mixed-strategy equilibrium. This is because, for any given probability of a collection attempt, an increase in the number of creditors increases the probability of bankruptcy at $t_{0}$, and thus increases each creditor's expected benefit from refraining. This result is not an example of effective deterrence, however, because what drives self-restraint in equilibrium is each creditor's assumption that other creditors will collect. And collection destroys synergy among the firm's assets. 
be indifferent between attempting to collect and refraining. If the creditor believes that the others will attempt collection with significantly less than 96 percent probability, the enhanced chance that others might refrain will make it more attractive for the creditor to attempt collection than to refrain. ${ }^{30}$

The point here is that each creditor will attempt to collect unless it believes there is a high probability that other creditors' attempts to collect will force the firm into bankruptcy within the preference period. Admittedly, I have used only a single example as an illustration. But one may generalize from the example without altering the basic result that no creditor will be likely to act in a way that might preserve the firm's going-concern value except where other creditors will destroy that value. ${ }^{31}$ This result may not hold if collection costs are high relative to the depth of a firm's insolvency, in which case each creditor will have something to lose by engaging in a race to assets, but little to gain by winning. Even so, preference law does not generally seem to be a source of effective collection deterrence.

The picture of preference law as collection deterrent does not brighten significantly in a richer model that accounts for various measures of a firm's going-concern surplus over liquidation value. One might imagine, for example, that not just the first, but every

30 If a creditor assumes that every other creditor attempts collection 95 percent of the time, the creditor will expect about $\$ 5.06$ from attempting collection and will expect about $\$ 4.93$ from refraining. This may be calculated using the binomial distribution formula in note 27. See also Rasmusen, Games and Information at 72-73 (cited in note 9). Compare Alan Schwartz, Bankruptcy Workouts and Debt Contracts, 36 J L \& Econ 595, 611-13 (1993) (discussing mixed-strategy equilibria in workouts); Robert Gibbons, Game Theory for Applied Economists 39-40 (Princeton, 1992) (describing mixed-strategy equilibria by reference to uncertainty respecting player strategies).

31 A generalization of the example in the text could take many forms. The example is based on the following model. Assume that a firm is subject to $n$ creditors, each holding (for simplicity) the same general debt of $d$, so that the firm's total debt is nd. Let $V_{g}$ be the firm's going-concern value, and let $V_{1}$ be the firm's liquidation value. Assume that $n d>V_{s}$ $>V_{l}$. Let $n_{c}$ be the number of creditors that attempt to collect and assume that $n_{b}$ is the number of creditors whose attempts to collect will result in a bankruptcy within the voidable preference period for any collection. Assume that $n_{l}$ is the number of creditors whose attempts to collect will, if $n_{l} \leq n_{b}$, reduce the value of the firm from $V_{g}$ to $V_{l}$. If $n_{l}>$ $n_{b}$, no attempt to collect can reduce the value of the firm from $V_{g}$ to $V_{l}$. Finally assume that $e$ is the collection expense for any creditor and that bankruptcy is costless.

In this model, the collection or bankruptcy payoff to a creditor that attempts to collect will be $d-e$ if $n_{c}<n_{b}$, will be $(d / n d) V_{g}-e$ if $n_{l}>n_{b}$ and $n_{c} \geq n_{b}$, and will be ( $d$ / $n d) V_{l}-e$ if $n_{c} \geq n_{b} \geq n_{l}$. The bankruptcy payoff to a creditor that refrains will be ( $d /$ ( $n d$ $\left.\left.n_{c} d\right)\right)\left(V_{g}-n_{c} d\right)$ if $n_{c}<n_{b}$ and $n_{c}<n_{l}$, will be $\left(d /\left(n d-n_{c} d\right)\right)\left(V_{l}-n_{c} d\right)$ if $n_{l} \leq n_{c}<n_{b}$, will be $(d$ Ind) $V_{g}$ if $n_{l}>n_{b}$ and $n_{c} \geq n_{b}$, and will be $(d / n d) V_{l}$ if $n_{c} \geq n_{b} \geq n_{l}$. Thus, unless $e$ is large or, relative to $e$, the applicable of $V_{g}$ or $V_{l}$ close to $n d$, there is no equilibrium for $n_{c}<n_{b}$. And if $n_{c} \geq n_{b}$, preference law will have served no deterrent purpose. 
creditor's collection reduces the aggregate value of a firm's assets-counting both those removed and not removed. If at $t_{0}$ each creditor assesses a positive probability of bankruptcy within the preference period, each creditor will deduct from its expected recovery its ratable share of the value the creditor will destroy by collecting, weighted by the probability of bankruptcy. Consequently, even if collection costs are trivial, each creditor might refrain if the product of value destruction through collection and the probability of bankruptcy within the preference period is large. This result does not depend on any creditor's prediction of others' actions if the probability of bankruptcy is independent of creditor collection. However, bankruptcy law essentially negates the possibility of an independent bankruptcy risk and with it the possibility that a creditor will assess both significant destruction from its own collection and a probability of bankruptcy within the preference period.

The probability of bankruptcy depends in fact on creditor collection because, unlike the rules of the simple collect-refrain game above, no automatic mechanism for initiating a collective proceeding exists-even for an insolvent firm and even after a period of time. The firm's managers may impose the collective process by filing a bankruptcy petition for the firm before there has been any collection activity. ${ }^{32}$ But managers may prefer to keep a financially distressed firm out of bankruptcy. Delaying bankruptcy may allow the managers to retain their own jobs and to extend equity's option on the firm's assets, which the managers may recklessly gamble. ${ }^{33}$ The managers' incentive for such delay leaves creditors with the task of forcing the collective proceeding. ${ }^{34}$ However, creditors generally cannot sustain an involuntary bankruptcy petition, or credibly threaten to sustain one, unless the debtor firm "is generally not paying such debtor's debts as such debts become due ...."35

32 See 11 USC $\$ 301$ (1988).

33 This view of management's incentive is commonly accepted. See Jackson, The Logic and Limits of Bankruptcy at 193-208 (cited in note 1). See also Susan Rose-Ackerman, Risk Taking and Ruin: Bankruptcy and Investment Choice, $20 \mathrm{~J}$ Legal Stud 277 (1991) (discussing managers' incentives regarding bankruptcy and liquidation options). Indeed, if managers faithfully invoked the collective process of bankruptcy to preserve a firm's going-concern surplus, voidable preference rules would be unnecessary.

${ }_{34}$ In fact, most bankruptcy petitions are technically "voluntary," that is, filed by management. However, managers often file voluntary petitions when the only alternative is an involuntary petition, see Jackson, The Logic and Limits of Bankruptcy at 201 (cited in note 1), perhaps filed in an unfavorable jurisdiction.

35 11 USC \& 303(h)(1) (1988). 
Despite some ambiguity, if a creditor acquiesces to nonpayment or late payment, current case law does not treat a debtor firm as having failed to pay its debts when they become due. ${ }^{36}$ Courts generally allow creditor petitions only when the debtor is in default, not when the debtor refinances or rolls over debt. ${ }^{37}$ Effectively, then, in terms of the simple model above, ${ }^{38} t_{0}$ (but not the preference period) is infinitely long. Accordingly, no creditor can realistically hope to enjoy the benefits of self-restraint. If others refrain from collection as well, the firm's assets will remain indefinitely in the hands of cavalier managers. ${ }^{39}$ If other creditors collect, these creditors will destroy the value the individual creditor hopes to preserve by refraining.

Bankruptcy expense imposes another potential impediment to deterrence. I have thus far assumed such expense to be zero. In fact, however, bankruptcy costs are nonnegligible. ${ }^{40}$ If one factors these costs into a creditor's calculus, an attempt to collect in the hope of avoiding participation in a bankruptcy proceeding may become relatively more attractive than in a world of zero transaction costs.

36 See, for example, In re Better Care, Ltd., 97 Bankr 405, 409 (Bankr N D Ill 1989).

37 There is some case law that treats a debtor as having failed to pay debts when due even when creditors have extended further credit. See, for example, Matter of International Teldata Corp., 12 Bankr 879, 882 (Bankr D Nev 1981). But these cases tend to focus on the debtor's inability to pay debts as they become due. See id. Courts are reluctant to foreclose an involuntary petition when creditors forbear in collecting a debt or first attempt a workout rather than demand payment that could force dismemberment of the firm or could prematurely precipitate a bankruptcy petition as a defense to a dismemberment threat. See Matter of Win-Sum Sports, Inc., 14 Bankr 389, 392-93 (Bankr D Conn 1981). If, however, a debtor can show that it could have made the payments had creditors not refrained, petitioning creditors will have difficulty meeting "the burden of showing that [the debtor] was generally unable to meet its obligations as they fell due." Id at 392 (emphasis added).

${ }_{38}$ See note 31 and text accompanying notes 5-31.

39 This is an oversimplification. Creditors can and do obtain covenants that accelerate amounts due when a firm's assets fall below a specified level. To the extent that creditors can enforce these covenants and declare their loans in default, they can create a situation in which the debtor will not attempt to pay all of its debts when due. In such a situation, creditors can file an involuntary petition before the debtor's assets run dry. But covenants are not self-enforcing. And it may not be easy for a creditor to demonstrate that there has been a default sufficient to trigger an acceleration clause. The situation the text describes is realistic to the extent that the enforcement of such covenants is imperfect.

to See, for example, Lawrence A. Weiss, Bankruptcy Resolution: Direct Costs and Violation of Priority of Claims, $27 \mathrm{~J}$ Fin Econ 285 (1990) (discussing direct costs of bankruptcy). See also Sanjai Bhagat, James A. Brickley, and Jeffrey L. Coles, The Costs of Inefficient Bargaining and Financial Distress: Evidence from Corporate Lawsuits, $35 \mathrm{~J}$ Fin Econ 221 (1994) (discussing direct and indirect costs of financial distress); Tim C. Opler and Sheridan Titman, Financial Distress and Corporate Performance, $49 \mathrm{~J}$ Fin 1015 (1994) (discussing indirect costs of financial distress). 
As a final note, it bears mention that one might model the collect-refrain game not as a simultaneous game, but as a sequential game. Assume that creditors decide whether to attempt collection or refrain with full information of other creditors' "collect" or "refrain" decisions. Under these conditions, one might be able to imagine a scenario in which the preference rules provided substantial deterrence. If each creditor knew that its action to collect would, with certainty or virtual certainty, induce other creditors to collect in turn, either to capture assets or to induce a bankruptcy process that would force others to return assets, all within the preference period for the first collection, no creditor would be first to collect, provided the assets would not diminish prior to a collective proceeding. This scenario is unlikely, however. As noted above, while the creditors refrained, the managers might waste the firm's assets. Moreover, even assuming that managers would preserve asset value and at some specified point voluntarily bring the firm into bankruptcy, a sequential game could not occur unless creditors were in a position both to observe any prior creditor action and to respond within the preference period. Yet at some point prior to bankruptcy, some creditors will perceive that others will not have a chance to react and the game will become simultaneous at that point.

In sum, although the voidable preference rules may deter collection, there are many situations in which the law provides little deterrence even where collection is costly and destroys asset value. The analysis above thus confirms John McCoid's intuition, expressed more than a decade ago, that creditors often will collect because "there may seem to be much to gain and little to lose by doing so." 41

This is not to say that effective deterrence is beyond Congress's reach. A simple solution to preference law's impotence would be to remove the "failure to pay" restriction on involuntary bankruptcy petitions. There would be great deterrence if each creditor that feared destructive collection by others could sustain a bankruptcy petition unilaterally (or in combination with a few other creditors). ${ }^{42}$ In terms of the above simultaneous game

41 John C. McCoid, II, Bankruptcy, Preferences, and Efficiency: An Expression of Doubt, 67 Va L Rev 249, 264 (1981).

${ }^{42}$ In fact, an involuntary petition generally requires at least three creditors. See 11 USC $\S 303(b)$ (1988), amended by Bankruptcy Reform Act of $1994 \S 108(\mathrm{~b})$, Pub L No 103394,108 Stat 4106,4112 . In a more realistic example than that in the text, the presence of many creditors would trigger this restriction but also make it relatively unimportant compared to the "failure to pay" restriction, see 11 USC $\S 303(\mathrm{~h})(1)$, which is a serious 
modeled with collection costs, if each creditor has three choices-attempt collection, refrain, or force bankruptcy- "force bankruptcy" is a weakly dominant strategy, assuming the declaration is costless. "Force bankruptcy" weakly dominates "refrain" because the former has all the benefits of the latter and the additional benefit that no creditor's collection will survive the preference period. "Force bankruptcy" also dominates "collect" because each creditor knows that there will be a bankruptcy within its preference period, either because some creditor will play "force bankruptcy" or because the other four will play "collect." Each creditor will, therefore, save the collection costs and force bankruptcy. The result, at least in this simple model, is perfect deterrence.

It may not be wise, however, to enhance the collection deterrent effect of bankruptcy law because there may be unacceptable costs to such enhancement. For example, elimination of the "failure to pay" restriction from involuntary petitions could put firms at risk of strategic behavior by creditors who might use the threat of bankruptcy and consequent costs to obtain extracontractual benefits from a firm that would not benefit from the bankruptcy process. ${ }^{43}$ Limiting involuntary petitions to insolvent firms would not necessarily obviate this problem efficiently because a solvent but troubled firm could appear, and be adjudicated, insolvent or be adjudicated solvent only after an expensive contest. There would be similar problems with other methods of enhancing preference law's deterrent effect. Congress could, for example, impose a penalty on a creditor that collected from an insolvent firm. Because it is not always clear whether a firm is insolvent, despite the assumption of the simple model above, a creditor might charge a debtor firm a premium to compensate for the risk that it would either inadvertently incur such a penalty or forgo a desirable collection that would not threaten the firm's viability. ${ }^{44}$ The result could be that debt would be-

constraint on sustaining a bankruptcy petition against a firm with any number of creditors.

13 See generally F.H. Buckley, The Termination Decision, 61 UMKC L Rev 243, 25256 (1992) (discussing potential costs of creditor termination rights).

* Despite any advance promises, the creditor might not expect a warning from an insolvent firm's management, as the managers might well permit collection to stave off bankruptcy and preserve their own jobs as well as equity's option. A managerial announcement of insolvency is an announcement of a firm's inability to pay all debts. If debt is due, through the passage of time or through acceleration, and cannot be repaid, creditors can file an involuntary petition. See note 37 . 
come an inefficiently less attractive part of a firm's capital structure. ${ }^{45}$

More generally, it may not be in the investors' mutual interest to make collection more expensive, even when a firm is insolvent. As I explain below, this observation may justify preference law's administrative expense of adjudication and recapture even if the law provides no collection deterrence. ${ }^{46}$ Preference law may serve an entirely different function.

\section{The OVERINVESTMENT Problem}

Whether they are the shareholders' faithful agents or merely desirous of protecting their jobs, managers have an incentive to risk an insolvent firm's assets in the hope of a success that can preserve equity's option and can keep creditors from installing new management. ${ }^{47}$ If the potential payoff to the shareholders is high enough, managers may have the firm pursue even a negative-net-present-value project. ${ }^{48}$ Finance scholars have referred to this investment pattern as the "overinvestment problem."

A simple model of overinvestment will facilitate an explanation of how the voidable preference rules mitigate this problem. In this model, at $t_{0}$, a firm under equity's management ${ }^{50}$ has

45 An example of such inefficiency is that a penalty on collection could diminish the disciplinary function of debt. Debt ordinarily disciplines managers who know that their firms cannot expect continually to reinvest funds, but must pay earnings out to investors who have an option not to renew their loans. If the managers do a poor job, their firms will be able to borrow only on unfavorable terms, which will signal the market of the managers' incompetence. See, for example, Barry E. Adler, An Equity-Agency Solution to the Bankruptcy-Priority Puzzle, 22 J Legal Stud 73 (1993); Michael C. Jensen, Agency Costs of Free Cash Flow, Corporate Finance, and Takeovers, 76 Am Econ Rev Papers \& Proc 323 (1986); Frank H. Easterbrook, Two Agency-Cost Explanations of Dividends, 74 Am Econ Rev 650 (1984); Sanford J. Grossman and Oliver D. Hart, Corporate Financial Structure and Managerial Incentives, in John J. McCall, ed, The Economics of Information and Uncertainty 107 (Chicago, 1982). McCoid also rejects collection penalties, though on the grounds that penalties would fall in part on innocent creditors. See McCoid, $67 \mathrm{Va} \mathrm{L}$ Rev at 270 (cited in note 41 ).

${ }_{46}$ McCoid suggests that this expense máy be unjustified. $67 \mathrm{Va} L \mathrm{Rev}$ at 270-73 (cited in note 41 ).

47 See note 33 and accompanying text.

43 For a seminal work on management incentives, see Michael C. Jensen and William H. Meckling, Theory of the Firm: Managerial Behavior, Agency Costs and Ownership Structure, 3 J Fin Econ 305 (1976).

49 See, for example, Elazar Berkovitch and E. Han Kim, Financial Contracting and Leverage Induced Over- and Under-Investment Incentives, $45 \mathrm{~J}$ Fin 765, 766 n 5 (1990) (discussing how financial contracts affect overinvestment and underinvestment incentives and describing the overinvestment problem).

${ }^{50}$ Assume, for the purposes of this illustration, that a firm under equity's management suffers no managerial agency cost because the shareholders and managers are the 
fixed assets, $F$, and an option to purchase a project, $P$, which will have a value $P_{1}$ at $t_{1}$. For the sake of simplicity, ignore the passage of time between $t_{0}$ and $t_{1}{ }^{51}$ The value $P_{1}$ will be $P_{s}$ (the payoff if the project succeeds) with a probability of $\alpha$, and $P_{f}$ (the payoff if the project fails) with a probability of (1- $\alpha)$. Of course, $P_{s}$ $>P_{f}$. The cost of $P$ is $C$. At $t_{0}$, the firm is subject to initial debt, $D_{0}$, such that $D_{0}>F$ and $D_{0}>F+\alpha P_{s}+(1-\alpha) P_{f}-C$; that is, the firm is insolvent. $P$ is the only project in which management can have the firm invest. Given that the firm cannot use its fixed assets to purchase the new project, the firm may pursue project $P$ only if it raises new capital in the amount of $C .^{52}$ The firm will raise this capital, if at all, with new debt promising a payment of $D_{n}$ at $t_{1} \cdot{ }^{53}$ As the alternative is no return to equity, management will have the firm invest in $P$ wherever $F+P_{s}>D_{0}+D_{n}$. This condition is satisfied, of course, where $P_{s}>D_{n}$ by more than $D_{0}>$ $F$. Thus $D_{n}$ in part determines whether $P_{s}$ is sufficiently high that management will have the firm invest in $P$ even if $P$ is a negative-net-present-value project: $C>\alpha P_{s}+(1-\alpha) P_{f}$.

Ignoring the passage of time, a lender without a preexisting relationship to the firm will advance $C$ for $D_{n}=C$ if the loan is risk free. If a lender becomes a general creditor, ${ }^{54}$ even if all existing debt is general, the lender will advance $C$ only for $D_{n}>C$ because the loan will not be risk free: At $t_{1}$, with probability of at least (1- $\alpha), D_{0}+C>F+P_{1}$. And if, at $t_{1}, D_{0}+C>F+P_{1}$ while $D_{n}=C$, then $\left(D_{0}+D_{n}\right) /\left(F+P_{1}\right)>1$. If the project fails, then, no general creditor, including the new lender, will receive full repayment. Consequently, $D_{n}$ must be greater than $C$ to compensate a new lender for the risk that it will not receive $D_{n}$ at $t_{1}$.

same people with a unified interest.

${ }^{81}$ One could account for the passage of time by creating a more realistic model that includes interest rates. As part of such a model, a firm would ordinarily promise to pay back more than it received in loan proceeds even from a riskless loan. Such a model would detract from clarity and would not alter the implications of the illustration. Given that the conclusions described below apply beyond a model that ignores time, the discussion below uses the accepted term "net present value" even though "present" is unnecessary within the confines of the model.

${ }_{62}$ It simplifies this model to treat $F$ as fixed. But the analysis would not necessarily change significantly if $F$ were variable.

${ }^{63}$ It will later become apparent that raising the capital through new equity is implausible. See note 68 .

${ }^{54}$ General credit refers to unsecured credit without special priority. Secured credit, in contrast, gives a creditor a priority claim to the value of the property the debtor pledges as collateral. If the value of collateral is insufficient to repay a secured creditor's debt in full, the secured creditor holds a general claim for the deficiency. See 11 USC § 506(a) (1988). 
This requirement simply reflects the firm's risk of insolvency, despite its opportunity to invest in $P$.

To avoid this situation, management might offer a new lender security for $D_{n}$. If the firm has unencumbered assets or will have such assets after the investment in $P$, a pledge of those assets to the new lender could allow the firm to obtain $C$ for $D_{n} \approx C$, depending on the collateral's initial value and the variability of that value. Thus, the prospect of security permits management to obtain $C$ for a lower $D_{n}$ than is possible without security. Such a $D_{n}$ might be sufficiently low that the new project will be profitable to equity, although it is a negative-net-present-value investment for the firm. The firm's ability to offer security can make this difference for equity if, given $D_{n}=C,{ }^{55} F+P_{s}$ is greater than $D_{0}+D_{n}$, despite $\alpha P_{s}+(1-\alpha) P_{f}-C<0$. There are conceivable margins of $F+P_{s}$ over $D_{0}+D_{n}$ where $D_{n}=C$, such that where $D_{n}>C$ given a new general loan, $F+P_{s}$ would not be large enough to provide equity with a potential return from $P$.

It is also possible, however, that even where $D_{n}=C, F+P_{s}<$ $D_{0}+D_{n}$, so equity will gain nothing from undertaking $P$ : The question arises, then, whether management can exploit a loan from an existing creditor where equity cannot gain from a new lender's extension of credit even where fully secured. Assume management seeks to obtain $C$ from a lender that is already owed a portion of $D_{0}$. If all preexisting debt is general, management will be unable to obtain $C$ from an existing lender for $D_{n}<C$ unless the new project is a positive-net-present-value project. $^{56}$ If $P$ has a negative net present value, the firm's investment in $P$ will diminish the value of the lender's preexisting debt. Indeed, given that $P$ has a negative net present value, an existing lender will, if it can, demand a higher $D_{n}$ to finance $P$, which will diminish the value of the lender's existing loans. Thus, without more, the prospect of a loan from an existing creditor does not exacerbate the overinvestment problem. ${ }^{57}$

\footnotetext{
${ }^{65}$ For simplicity, assume that security to a new lender will produce a risk-free loan and thus permit $D_{n}=C$.

${ }_{56}$ This is true even if $F$ is variable, provided that the lender is or behaves as if it were risk neutral with respect to its investment in the firm. A typical investor does not prefer risk. If the lender behaves in a risk-averse fashion, it is theoretically possible for $D_{n}$ $<C$ even though this will diminish the expected value of the lender's preexisting debt. This is because a risk-averse investor will value the prospect that one project will succeed while the other fails. But diversification of investments among lenders and the likely positive correlation of $F$ and $P$, projects of the same firm, make an outcome of $D_{n}$ significantly less than $C$ unlikely absent security.

57 But see the qualification in note 56.
} 
The potential role of an existing creditor changes, however, if management has an opportunity to have the firm offer security not only for $D_{n}$ but also for the creditor's portion of $D_{0}$. Let $D_{e}$ represent the creditor's share of general debt $D_{0}$. If an existing creditor refuses to finance $P$, and no one else finances the project, the value of the creditor's claim at $t_{1}$ will be the creditor's ratable portion of $F$, which is less than the amount the insolvent firm owes the creditor. If the firm offers the creditor priority for all or some of $D_{e}$, the creditor might be willing to finance even a negative-net-present-value project for a $D_{n}<C{ }^{58}$ Imagine, for example, that management is able to have the firm offer an existing creditor full security for $D_{n}$ and security for some portion of $D_{e}$, the secured portion identified as $D_{s}$. In this case, $D_{n}=C-b$, where $b$, in part determined by $D_{s}$, is the extent of the creditor's benefit from the firm's grant of priority on the creditor's existing loan. ${ }^{59}$ That is, rather than suffer partial payment on all of $D_{e}$, the existing creditor might provide a new, fully secured loan to the firm larger than the amount the firm promises to repay.

This prospect of an existing lender taking security for new and preexisting debt, sometimes called cross-collateralization, exacerbates the overinvestment problem. To see why, consider a case in which $C>\alpha P_{s}+(1-\alpha) P_{f}$, that is, a case where $P$ is a negative-net-present-value project, but where $P_{s}-C<D_{0}-F$. Management will not invest in $P$ if the firm needs to attract capital from a new lender, even a fully secured one, because the new lender would require a $D_{n}=C$, and the firm would remain insolvent even if the value of the project at $t_{1}$ were $P_{s}$. The prospect of cross-collateralization, however, may make $P$ possible where it is not otherwise because cross-collateralization permits $D_{n}<C$ and thus might permit $P_{s}-D_{n}>D_{0}-F^{60}$

58 In a fully realistic example, this might be accomplished by a lender advancing a new loan with an interest rate below the market rate. See note 51. For clarity, this simple example omits discussion of interest rates.

${ }_{59}$ For this equation, $b=\alpha D_{e}+(1-\alpha)\left(D_{s}+\left(\left(D_{e}-D_{s}\right) /\left(D_{0}-D_{s}\right)\right)\left(F-D_{s}+P_{f}-D_{n}\right)\right)-\left(D_{e} /\right.$ $\left.D_{0}\right) F$, where $D_{x} \leq\left(F+P_{f}-D_{n}\right)$. The benefit, $b$, is the creditor's expected recovery if on management's request it extends the new loan minus what it will recover if it does not finance $P$, assuming no other lender will finance $P$. (For a description of competition among creditors to finance $P$, see note 66.) The text describes $b$ as a benefit under the assumption that it is positive, as it will be where $D_{z}$ is large enough to overcome the creditor's loss, limited to $D_{e}-D_{s}$, from the firm's investment in a negative-net-presentvalue project. For an application, see text accompanying note 66 .

${ }_{60}$ There is a similar analysis of exchange offers in Robert Gertner and David Scharfstein, A Theory of Workouts and the Effects of Reorganization Law, $46 \mathrm{~J}$ Fin 1189 (1991). See also Michelle J. White, The Corporate Bankruptcy Decision, $3 \mathrm{~J}$ Econ Persp 129, 134 (1989) (discussing coalitions between equity and creditor); Jeremy Bulow and 
Voidable preference rules may mitigate the overinvestment problem. The transfer of a security interest for a contemporaneous debt within the preference period is not voidable. ${ }^{61}$ However, the transfer of a security interest on account of antecedent debt within the preference period is voidable. ${ }^{62}$ Consequently, if management grants an existing creditor a security interest in property on account of preexisting debt, preference law voids that security interest if the firm enters bankruptcy within the preference period following the grant of the security interest. ${ }^{63}$ The existing creditor will, therefore, discount the value of $b$ by its estimate of the probability of a bankruptcy within the preference period. As $b$ approaches zero (because $D_{s}$ effectively approaches zero), $D_{n}$ approaches $C$ and the role of cross-collateralization in the overinvestment problem approaches insignificance.

A numerical example further illustrates this conclusion. Assume $D_{0}=\$ 100$ of general debt while $F=\$ 89$. Assume also that $P_{s}=\$ 20, P_{f}=\$ 8$, and $\alpha=10$ percent while $C=\$ 10$. Thus, the expected payoff of $P$ at $t_{0}, P_{0}=\$ 9.20,{ }^{64}$ and $P$ is a negativenet-present-value project. Even a fully secured new lender will demand $D_{n}=\$ 10$ and management will have no incentive to have the firm pursue $P$ if financed by such a lender because in this case $D_{0}+D_{n}>P_{s}+F$; that is, $\$ 110>\$ 109$. Put another way, $D_{n}$ would be above the $\$ 9$ threshold for investment.

Now assume that there exists a creditor with $D_{e}=\$ 10$. If the firm were able to fully secure this creditor's preexisting debt, so $D_{s}=\$ 10$, as well as the new debt, the creditor might accept little more than $D_{n}=\$ 8.90$ to advance $C=\$ 10$. (The creditor could afford to sacrifice up to $\$ 1.10$ because $D_{s}$ would be $\$ 1.10$ more

John Shoven, The Bankruptcy Decision, 9 Bell J Econ 437, 440 (1978) (same). For an exposition of related problems in a discussion of debtor-in-possession financing, see George G. Triantis, A Theory of the Regulation of Debtor-In-Possession Financing, 46 Vand L Rev 901 (1993). Triantis expressly declines to analyze cross-collateralization, however. Id at 907. Compare Hideki Kanda and Saul Levmore, Explaining Creditor Priorities, 80 Va L Rev 2103 (1994) (arguing that overinvestment issues help explain creditor priority).

${ }_{61}$ See 11 USC $\$ 547(\mathrm{~b})(2)(1988)$. Indeed, as discussed in the text below, collection of a secured loan within the preference period is also not voidable. See 11 USC \& 547(b)(5) (1988).

${ }_{62}$ See 11 USC \& 547(b) (1988) (defining a voidable transfer to include "any transfer of an interest of the debtor in property").

${ }_{63}$ See, for example, In re Saybrook Manufacturing Co., Inc., 963 F2d 1490, 1496 (11th Cir 1992), citing In re Texlon Corp., 596 F2d 1092, 1097 (2d Cir 1979) (noting that if crosscollateralization were initiated by the bankrupt while insolvent and shortly before filing a petition, the arrangement would have constituted a voidable preference).

64 That is: .1( $(\$ 20)+.9(\$ 8)$. 
than $\left(D_{e} / D_{0}\right) F=\$ 8.90,{ }^{65}$ the creditor's share of the firm without the cross-collateralization and without the project. ${ }^{66}$ But for the voidable preference rules, management would have the firm invest in $P$ because $\left(D_{0}+D_{n}=\$ 108.90\right)<\left(P_{s}+F=\$ 109\right)$.

If this creditor believes, however, that a poor outcome of the project, $P_{f}$, will with certainty precipitate collection attempts by other creditors and a consequent bankruptcy petition within the creditor's preference period, the creditor will, despite full security, demand to be compensated with $D_{n}>\$ 10$ for financing the negative-net-present-value project, because the project will diminish the creditor's expected return on its preexisting debt. ${ }^{67}$ This, of course, may not be quite correct, because a new lender might provide $C=\$ 10$ for $D_{n}=\$ 10$. That an existing creditor will demand more than $\$ 10$ assumes that the existing creditor is the only source of financing for $P$. In any case, no existing lender will offer $D_{n}<\$ 10$ without security for $D_{e}$ because $P$, a negative-netpresent-value project, necessarily reduces the expected return on $D_{0}$ and, consequently, on any unsecured $D_{e}{ }^{68}$ Thus, because voidable preference rules inhibit security, they have the potential to inhibit investment in negative-net-present-value projects.

This observation may solve one puzzle left unsolved by the collection deterrence justification of voidable preference law. As noted in Part I, that justification attributes to preference law the savings from avoided collection costs and avoided destruction of going-concern surplus. A creditor that acquires a security interest for an antecedent debt may incur the equivalent of collection costs, but the security interest in no way jeopardizes a firm's going-concern surplus. No assets are stripped, and thus the justification for avoidance seems weak. The standard response is that the savings from avoided collection costs themselves justify the

${ }^{65}$ That is: $(\$ 10 / \$ 100) \$ 89$.

66 There would be no collective-action problem like that discussed in Part I even if there were other unsecured creditors with $\$ 10$ of unsecured debt. Each such creditor would prefer to provide $C$ at a discount rather than be left behind to bear the cost of $P$. Indeed, such creditors might be expected to bid $D_{n}$ down below $\$ 8.90$. For the sake of simplicity, I ignore this possibility in this example.

${ }_{6}$ If $D_{n}=\$ 10$, assuming for the sake of illustration that the project would go forward despite the lack of a potential payoff to equity, the creditor would expect: .1( $(\$ 10 / \$ 100)$ $(\$ 89+\$ 20-\$ 10))+.9((\$ 10 / \$ 100)(\$ 89+\$ 8-\$ 10))=\$ 8.82$, an amount less than the creditor would receive without the project.

${ }^{68}$ For the sake of completeness, note that management could not have the firm finance $P$ with new equity capital from a risk-neutral investor. Because $D_{0}>F$ and $P$ has a negative net present value, a new contribution of equity invested in $P$ would provide an equity investor an expected payoff less than the contribution. 
avoidance of security interests. ${ }^{69}$ But as Tom Jackson concedes, elimination of a race to assets or to achieve priority therein is not a pure benefit. The absence of a race may also entail the absence of creditor monitors who, in anticipation of a race, might monitor and prevent management misbehavior. ${ }^{70}$ Thus, the standard justification fails fully to support voidable preference law. Overinvestment analysis provides an alternative justification precisely where one is needed.

The overinvestment analysis, moreover, has applications beyond the examples discussed thus far. For instance, an existing creditor may be viewed as supplying a new loan without providing new funds. Imagine an existing creditor that may, according to its contract, at $t_{0}$ demand repayment of some, but not all, of an antecedent debt. In this case, the analysis above could apply with some portion of the amount due $C$, some portion of that $D_{n}$, and the amount not due $D_{e}$. Indeed, under these assumptions the voidable preference rules have an even greater effect on overinvestment, because application of the rules would void the security for $D_{n}$ as well as $D_{e}$.

Furthermore, the priority that can lead to overinvestment need not be a security interest in specific collateral. Without preference law, management might promise an existing creditor repayment of both a new and a preexisting loan prior to the maturity of a firm's other loans, perhaps at the creditor's demand. ${ }^{71}$ Early repayment, perhaps just prior to financial collapse and bankruptcy, would like ordinary security provide a creditor with priority over other creditors.

There are situations in which management would prefer to use early maturity rather than security as a means of offering priority. A firm may be subject to general creditor covenants that prohibit any subsequent loans or subsequent high-priority loans. When a firm is in financial distress, its managers may be willing to breach such a covenant to obtain financing that could extend both the managers' control and equity's interest. A breach of covenant will accelerate the amounts due on the original general debt and foil management's plan, but only if the general creditors discover the breach. The perfected grant of a security interest

69 See Jackson, The Logic and Limits of Bankruptcy at 128 (cited in note 1).

70 Id at 18.

${ }^{71}$ Compare Gertner and Scharfstein, $46 \mathrm{~J}$ Fin at 1213-14 (cited in note 60) (discussing creditors' and managers' investment incentives and debt maturity). 
ordinarily requires a public filing. ${ }^{72}$ A loan with an early maturity, including a demand loan, is more easily hidden. To the extent that voidable preference law devalues collection on an early-maturity loan, ${ }^{73}$ it provides a barrier to such mischief.

Finally, it proves useful to examine the risk of overinvestment in a firm that has no unencumbered value at the time management seeks a new loan. A particular insolvent firm might have unsecured debt, secured debt, and a total asset value less than the secured debt. Such a firm might be a good candidate for liquidation. Put another way, every day it continues in operation might be negative-net-present-value investment. Suppose such a firm will cease operation immediately unless it receives an infusion of new funds. Also assume that unless the new loan is secured or otherwise senior, these funds are unavailable at a price that permits equity a payoff even if continuation has an unexpectedly good outcome. But, contrary to the earlier examples, assume that if the new loan is high priority the firm can obtain the new loan for a price sufficiently low to permit continuation despite the firm's inability to offer new security on any preexisting debt. In the terms of the above model, assume it is sufficient for $F+P_{s}>D_{0}+D_{n}$ that $D_{n}$ is risk free.

If this firm purchases encumberable assets with the new funds, preference law does not inhibit inefficient continuation because the grant of an interest to secure a contemporaneous obligation is not a voidable preference even if it occurs within the preference period. ${ }^{74}$ But assume, as may often be the case for failing firms, that the firm will use the new funds to pay employees or to pay other creditors amounts currently due so that those creditors cannot attempt to collect from assets vital to continuation. In this case, properly interpreted, preference law could be a barrier to overinvestment. Here that overinvestment is continuation.

To understand this, one must focus on the methods management may use to grant the new loan priority status. The firm might promise the lender priority in the product of the

72 See UCC $\S \S 9-302,9-401$.

73 There are a number of exceptions to avoidance for collections within the preference period, most notably the exception for collection in the ordinary course of business of loans made in the ordinary course of business. See 11 USC $\$ 547$ (c)(2) (1988) (defining the ordinary-course exception). See also Part IV. The collection of recent loans on the eve of other creditors' maturity and the firm's financial collapse, however, does not fit into any exception.

"See note 61. 
employees' services without a security interest by inviting the lender to collect before maturation of the firm's other obligations. If such collection occurs within the preference period, it will be voidable. ${ }^{75}$ The firm might instead offer the lender a security interest in the product of the employees' services, that is, in inventory produced, accounts receivable, or the proceeds thereof. Preference law would treat such product, by necessity subsequent to the loan, as a transfer of a security interest on account of antecedent debt. ${ }^{76}$ To the extent such product accumulates during the preference period, the lender's security in the product may be void if such accumulation is "to the prejudice of other creditors. ${ }^{\text {n7 }}$

The overinvestment analysis in this Part demonstrates that any accumulation of inventory or accounts may be to the prejudice of other creditors, regardless of the limitations in the traditional justification for voiding security interests in such accumulations. According to that justification, such avoidance "may be seen as implementing the preference section's anti-last-minutegrab policy by way of a presumptive rule. ${ }^{78}$ The presumption is that interested creditors might influence debtors to convert other types of assets to inventory or to accounts, perhaps through "crash sales. ${ }^{\text {"79 }}$ Consistent with this standard justification, there has been some thought that the accumulation of inventory or accounts through "completing work in process [or] sales of inventory ${ }^{\prime \prime 0}$ is not voidable under the preference rules inasmuch as such activity is not "to the prejudice of other creditors. ${ }^{381}$ But when one considers the risk of overinvestment, it becomes clear that the completion of work in process and the sale of inventory are proper subjects of voidable preference scrutiny.

\section{The UnderInVESTMent Problem}

Analysis of an insolvent firm's overinvestment problem provides a stronger justification for voidable preference rules than

${ }^{75}$ See 11 USC \& 547(b).

${ }^{76}$ See 11 USC $\$ 547(\mathrm{e})(3)(1988)$.

$\pi 11$ USC § 547(c)(5) (1988).

${ }^{78}$ See Jackson, The Logic and Limits of Bankruptcy at 143 (cited in note 1).

79 Thomas H. Jackson, Avoiding Powers in Bankruptcy, 36 Stan L Rev 725, 774-75 n 157 (1984), quoting National Bankruptcy Conference, Report of the Commission on Coordination of the Bankruptcy Act and the Uniform Commercial Code (1970).

so United States Commission on the Bankruptcy Laws of the United States, Report of the Commission on the Bankruptcy Laws of the United States: Part I 222 (1973).

${ }_{81} 11$ USC \& 547(c)(5). 
does the standard justification. Overinvestment, however, is not theoretically certain even in the absence of preference rules. Just as managers of an insolvent firm have an incentive to invest the firm's assets in high-risk, negative-net-present-value projects, the same managers have insufficient incentive to invest the firm's assets in low-risk, positive-net-present-value projects. The latter phenomenon is sometimes called the underinvestment problem. ${ }^{82}$ Just as denying priority for new and preexisting loans mitigates the overinvestment problem, it exacerbates the underinvestment problem. ${ }^{83}$ As a result, it is not always clear whether preference law promotes efficiency.

The example used to demonstrate the overinvestment problem in Part II, slightly modified, illustrates the underinvestment problem. Again assume that at $t_{0}$, a firm under equity's management has fixed assets $F$ and an option to purchase project $P$, which will have a value at $t_{1}$ of $P_{s}$ with a probability of $\alpha$, and of $P_{f}$ with a probability of (1- $\left.\alpha\right)$. Again ignore the passage of time. ${ }^{84}$ Again, the price of $P$ is $C$, and $P$ is the only project in which management will have an opportunity to have the firm invest. And again the firm is insolvent. That is, at $t_{0}$, the firm is subject to initial debt, $D_{0}$, such that $D_{0}>F$ and $D_{0}>F+\alpha P_{s}+(1-\alpha) P_{f}$ $C$. As before, management will have the firm invest in $P$ only if $F$ $+P_{s}>D_{0}+D_{n}$, where $D_{n}$ is the amount of the promise a lender will demand from the firm in exchange for $C$. Also as in the prior

${ }^{82}$ The seminal work on the underinvestment problem is Stewart C. Myers, Determinants of Corporate Borrowing, $5 \mathrm{~J}$ Fin Econ 147 (1977).

83 For a discussion of this trade-off, see, for example, Triantis, 46 Vand L Rev at 91027 (cited in note 60); Gertner and Scharfstein, $46 \mathrm{~J}$ Fin at 1195, 1214-15 (cited in note 60); Berkovitch and Kim, $45 \mathrm{~J}$ Fin at 773-83 (cited in note 49). See also, for example, Robert $\mathrm{K}$. Rasmussen, The Ex Ante Effects of Bankruptcy Reform on Investment Incentives, 72 Wash U L Q 1159 (1994) (generally discussing bankruptcy over- and underinvestment in firms subject to bankruptcy law); Alan Schwartz, The Absolute Priority Rule and the Firm's Investment Policy, 72 Wash U L Q 1213 (1994) (addressing underinvestment and other inefficiencies that result from breaches in absolute priority); Barry E. Adler, Bankruptcy and Risk Allocation, 77 Cornell L Rev 439, 473-75 (1992) (discussing breaches of absolute priority and overinvestment); Yaacov Z. Bergman and Jeffrey L. Callen, Opportunistic Underinvestment in Debt Renegotiation and Capital Structure, $29 \mathrm{~J}$ Fin Econ 137 (1991) (discussing the reorganization bargaining game between creditors and managers and the potential for underinvestment); Karen Hopper Wruck, Financial Distress, Reorganization, and Organizational Efficiency, $27 \mathrm{~J}$ Fin Econ 419 (1990) (discussing financial distress and its effect on organizational efficiency); Rene M. Stulz and Herb Johnson, $A n$ Analysis of Secured Debt, $14 \mathrm{~J}$ Fin Econ 501, 515-19 (1985) (discussing secured debt's mitigation of the underinvestment problem); Varouj A. Aivazian and Jeffrey L. Callen, Corporate Leverage and Growth: The Game-Theoretic Issues, $8 \mathrm{~J}$ Fin Econ 379 (1980) (discussing implications of the underinvestment problem for pricing and valuation of risky assets).

st See note 51. 
illustration, assume $F=\$ 89, D_{0}=\$ 100$ of general debt, $\alpha=10$ percent, $C=\$ 10$, and $P_{s}=\$ 20$. Assume here, however, that $P_{f}=$ $\$ 9$ and that, as a consequence, $\alpha P_{s}+(1-\alpha) P_{f}>C$. That is, assume $P$ is a positive-net-present-value project with a $P_{0}=\$ 10.10 .^{85}$

Again assume a fully secured new lender will provide $C$ for $D_{n}=\$ 10$. Consequently, $\left(D_{0}+D_{n}=\$ 110\right)>\left(P_{s}+F=\$ 109\right)$, and management will forgo the project unless the firm can obtain $C$ on more favorable terms (or the managers have some unmodeled incentive to pursue the project). In this example, however, the forgone project will be a valuable one.

Now consider a potential new loan from an existing creditor with a preexisting general debt of $D_{e}=\$ 10$. If the firm can offer this creditor security for $D_{e}$, creating $D_{s}=\$ 10$, as well as security for $D_{n}$, the creditor might advance $C=\$ 10$ for $D_{n}$ just above $\$ 8.90$, below the $\$ 9$ investment threshold. (A $\$ 1.10$ increase in return on $D_{e}$ would offset a $\$ 1.10$ concession. $)^{86}$

Because of the incentive to free ride, there are circumstances in which no creditor would make the necessary concession even if at least one creditor had sufficient $D_{e}$ to justify the minimum concession and preference law did not interfere with crosscollateralization. This could be the case where each of multiple creditors would gain from security for $D_{e}$ if it made the needed concession, but would gain more from its ratable share of $P$ if another creditor made the concession. ${ }^{87}$ In this case, each creditor might hope to free ride, ${ }^{88}$ counting on another creditor to provide the concession. ${ }^{89}$ Still, such free riding would not be cer-

85 That is: .1(\$20)+.9(\$9).

86 Considered without $P$, the creditor expects $\$ 8.90$ from its preexisting debt: $(\$ 10$ / $\$ 100) \$ 89$.

${ }_{87}$ For a creditor with a large preexisting general debt of an insolvent firm, the potential gain from security for that debt in exchange for a modest concession could overwhelm any advantage, described below, of free riding on a positive-net-present-value project financed by another's concession.

${ }_{88}$ Attempts at free riding create a variant of the collective-action problem described in Part $\mathrm{I}$.

89 This is easy to see by assuming that for no creditor $D_{c}>\$ 10$ and that $P_{f}$ is not $\$ 9$, but $\$ 12$, for example. It remains true that $P_{s}+F<D_{0}+C$. Thus, $P$ is insufficient to make the firm solvent: $F+\alpha P_{s}+(1-\alpha) P_{f}-C=\$ 89+.1(\$ 20)+.9(\$ 12)-\$ 10=\$ 91.80$, which is less than $D_{0}=\$ 100$. No new investor would finance the project according to terms that would give management any chance of a return. A concession of slightly more than $\$ 1$ from an existing creditor with $D_{c}=\$ 10$ might be possible, given that a concession of $\$ 1$, the threshold for management's investment incentive, would provide such a creditor a return of $D_{\varepsilon}+D_{n}-C=\$ 9$, assuming $D_{s}=D_{e}=\$ 10$. This return is more than the creditor would receive without a concession and without $P$, because without the project and with $D_{s}=\$ 0$ the creditor would receive $(\$ 10 / \$ 100) \$ 89=\$ 8.90$. However, if a creditor with $D_{\text {s }}$ $=\$ 10$ believed another creditor with $D_{e}=\$ 10$ would provide the minimum $\$ 1$ concession, 
tain $^{90}$ and the availability of cross-collateralization might prevent underinvestment.

Cross-collateralization might not be viable in the face of preference law, however. To continue with the last illustration, assume, as in Part $I I,{ }^{91}$ that each potential secured lender believes a poor outcome of the project, $P_{f}$, will cause collection attempts by other creditors and a consequent bankruptcy petition within the creditor's preference period. Under these circumstances, a creditor with $D_{e}=\$ 10$ will not provide $C=\$ 10$ for $D_{n}$ as little as the $\$ 9$ threshold for investment.

To see why, consider the plight of an existing creditor with $D_{e}=\$ 10$ who makes a fully secured new loan of $C=\$ 10$ for $D_{n}=$ $\$ 9$ and who receives security for its preexisting loan. With a good result, $P_{s}$ will provide the creditor a return on $D_{e}$ that is $\$ 1.10$ better than the status quo. That is, the creditor will receive $\$ 10$ instead of $\$ 8.90$. A poor result, $P_{f}$, coupled with the avoidance of security for $D_{e}$-due to the bankruptcy-will provide the creditor with an $\$ 8.90$ return on $D_{e}$ just as if there were no project. ${ }^{92}$ Given that $P_{s}$ carries only a 10 percent probability, if $D_{n}=\$ 9, P$ will provide the creditor with an expected gain of $\$ 0.11$ on $D_{e}{ }^{93}$ That amount is less than the $\$ 1$ concession for providing $C=\$ 10$ at $D_{n}$ $=\$ 9$. Consequently, the voidable preference rules here inhibit the firm's ability to mitigate the underinvestment problem by offering security for preexisting debt.

This example, like the analogous one of overinvestment, can be generalized. Wherever the preference rules limit priority available to a lender contemplating new credit, there is a risk that the preference rules will yield underinvestment. It is immaterial whether the affected priority is a security interest or an early maturity loan. To be sure, the problem is limited in importance

with $D_{n}=\$ 9$ and $D_{s}=\$ 10$, the first creditor would expect $\alpha D_{e}+(1-\alpha)\left(D_{e} /\left(D_{0}-D_{s}\right)\right)(F-$ $\left.D_{s}+P_{f}-D_{n}\right)=.1(\$ 10)+.9(\$ 10 /(\$ 100-\$ 10))(\$ 89-\$ 10+\$ 12-\$ 9)=\$ 9.20$. Thus a creditor with $D_{e}=\$ 10 \mathrm{might}$ attempt to free ride. Fraudulent transfer law would prohibit management from providing a creditor a payoff of more than $D_{e}$ in the event the project failed and thus would foil management's attempt to overcome a free-rider problem through the promise of a side payment. See 11 USC $\$ 548$ (1988) (providing bankruptcy rules of fraudulent transfers).

${ }^{90}$ Even if there are multiple creditors that might each attempt to free ride, it is possible that one or more would offer to provide the necessary concession for fear that another might not. Compare text accompanying notes 25-31.

${ }^{31}$ See text accompanying note 67.

92 If the project has a poor outcome, the assets of the firm will be $F+\$ 9$. The new loan will have a priority claim of $\$ 9$, leaving $F$ to be divided among the preexisting claims as if the project had been forgone.

${ }^{3}$ That is: .1( $\left.\$ 1.10\right)+.9(\$ 0)$. 
to the transaction costs of agreement among management and existing creditors because, when the potential inefficiency is underinvestment, it is in the collective interest to finance the project in question and, through collective agreement, to eliminate any effect of bankruptcy law. ${ }^{94}$ But, in theory, collective agreement can solve any insolvency problem (including overinvestment). Because attempts at collective action may fail, the problem of underinvestment can be real. Indeed, Congress apparently partially understood the risks of underinvestment, as evidenced by the Bankruptcy Code's forebearance with respect to preference-period collection of debt secured contemporaneously with the extension of credit or prior to the preference period..$^{95}$

The principal implication of this underinvestment analysis is that one should not be uncritical of the rules that effectively strike down preference-period grants of priority. Contrast the view of Thomas Jackson, who, while dubious of the harm from preference-period security, opines: "Nonetheless, such actions, if engaged in on account of existing debts with an eye toward an impending bankruptcy, ... fail to offer any affirmative value that might [ ] justify them." ${ }^{\prime 96}$ A view of preferential transfers through the lens of investment incentives complicates the picture beyond this traditional analysis. Part II of this Article establishes overinvestment as a harm Jackson does not identify, while this Part offers underinvestment mitigation as an affirmative value that Jackson finds lacking. The task now is to weigh harm against benefit.

\section{BALANCING OVER- AND UNDERINVESTMENT CONCERNS}

Although preference law deters both good and bad projects, one need not be agnostic about the efficacy of the law. Preference law and its effects on over- and underinvestment are concerns of insolvent firms. ${ }^{97}$ And insolvency is not itself indiscriminate. It

*4 See Aivazian and Callen, $8 \mathrm{~J}$ Fin Econ at 380-82 (cited in note 83).

${ }^{95}$ See 11 USC $\$ 547(\mathrm{~b})(5)$. See also Irving A. Breitowitz, Article 9 Security Interests as Voidable Preferences, 3 Cardozo L Rev 357, 358-63 (1982) (discussing $\$ 547$ and its legislative history).

${ }_{96}$ Jackson, The Logic and Limits of Bankruptcy at 128 (cited in note 1).

${ }^{27}$ Strictly speaking, these could be concerns of a solvent firm as well. A richer model than that used in this Article would take into account the possibility that a solvent firm could become insolvent during the preference period. Given the risk of insolvency, there are conditions under which a solvent firm can suffer from over- or underinvestment as described in this Article. And while, technically, a preferential transfer is not voidable unless the debtor is insolvent at the time of the transfer, see 11 USC $\$ 547(b)(3)$, because the state of solvency is not always certain, it is relevant that the law presumes insolvency 
may be exceedingly likely that the plight of any particular insolvent firm is the result of its systematic and continuing failure to produce goods or services efficiently. In other words, although unexpected changes in the economy and failed gambles by good firms are possible, such events may be less likely than the traditional reason for business insolvency, a bad idea poorly executed. ${ }^{98}$ If so, preference law's discouragement of investment may enhance social welfare relative to a world without voidable preference rules. ${ }^{99}$

Moreover, it is easy to overstate the relative importance of voidable preference rules as they affect underinvestment, even if one assumes that underinvestment poses a problem as frequently as overinvestment. Recall that the illustrations in Parts II and III describe a creditor's incentive to sacrifice repayment of a new loan in exchange for the debtor's grant of security for an existing loan. Preference law voids that grant of security if bankruptcy occurs within the preference period following the grant. The prospect of such avoidance may inhibit overinvestment or exacerbate underinvestment. But underinvestment may be relatively intractable.

To understand the relatively larger effect preference law may have on overinvestment than on underinvestment, note that where the problem is overinvestment, but for preference law, it could be common that each creditor would be anxious to finance a poor investment in exchange for security that would protect it from the consequences of that investment. Thus, the avoidance of security may well discourage poor investment. It does not necessarily follow, however, that repeal of the voidable preference

during the ordinary ninety-day preference period. See 11 USC $\S 547(f)$ (1988). As a practical matter, then, preference law may affect a solvent firm's investment decisions. However, unless a firm is insolvent or nearly so, there may be little likelihood of insolvency in the near term. Thus the implication in the text that preference law is unimportant for healthy firms.

\$8 I argue for this proposition, despite debt's traditionally ascribed role as a management disciplinary device, in Barry E. Adler, A Theory of Corporate Insolvency (unpublished manuscript on file with U Chi L Rev). Compare Schwartz, 72 Wash U I Q at 1217 (cited in note 83) (" $[\mathrm{A}]$ firm's cash flows would seem generally to have high serial correlations .....").

${ }^{90}$ Compare the point in Triantis, 46 Vand $L$ Rev at 925 (cited in note 60), citing Elazar Berkovitch and Ronen Israel, The Bankruptcy Decision and Debt Contract Renegotiations (unpublished manuscript), that overinvestment is the more common problem because, in the debt renegotiation process, equity holders prefer to conceal from creditors their intention to have a firm take undue risks while they readily reveal to creditors those profitable opportunities that the firm will forgo unless there is a renegotiation. See also text accompanying note 94 . My analysis does not depend on information asymmetry. 
rules would significantly encourage desirable investment. As described in Part III, even without preference law, creditors might not be anxious to finance a proposed investment in exchange for security where a concession on the new loan would dissipate some part of the gain security would provide. Each creditor might attempt to free ride on the hoped-for concession of another creditor. Put simply, creditors facing overinvestment do not want to suffer the effects of the investment, while creditors facing underinvestment may benefit from a project others finance. ${ }^{100}$ Consequently, to the extent that voidable preference rules inhibit cross-collateralization (and analogous methods of offering priority, such as a promise of early repayment), they inhibit overinvestment but may do little to exacerbate underinvestment.

In sum, the prospect of an insolvent firm's inviability combined, where relevant, with the impotence of new priority to mitigate underinvestment makes it plausible to assume that preference avoidance does more good than harm for most firms.

One might therefore question exceptions to the avoidance of certain transfers on the eve of bankruptcy. For example, collection of a fully secured debt within the preference period is not a voidable preference. ${ }^{101}$ The accepted reason for this exception is that a holder of a fully secured claim has no interest in racing to collect assets because such a holder will be fully repaid at the end of the bankruptcy process without collecting in advance. Thus, the rule apparently reflects a judgment that such collections do not threaten the common pool. ${ }^{102} \mathrm{~A}$ traditional criticism of this exception is that even a holder of a fully secured claim may benefit from early collection, and thus may not be easily dissuaded from even a destructive collection attempt, ${ }^{103}$ at least because such creditor is not guaranteed compensation for forgone reinvestment of its collateral's value. ${ }^{104}$ This Article's analysis of over- and underinvestment provides another criticism of the exception: Any facilitation of secured lending to an insolvent firm

100 But see notes 86-90 and accompanying text.

101 See 11 USC § 547(b)(5). See also Breitowitz, 3 Cardozo L Rev at 366-67 \& n 37 (cited in note 95).

102 See Douglas G. Baird, The Elements of Bankruptcy 169 (Foundation, 1993).

103 See id.

${ }_{104}$ See United Savings Ass'n of Texas $v$ Timbers of Inwood Forest, 484 US 365, 372-74 (1988) (providing that undersecured creditors are not entitled to protection of bankruptcy pendency reinvestment income even though, and in part because, under 11 USC $\$ 506(\mathrm{~b})$ (1988), oversecured creditors are explicitly entitled to pendency interest to the extent of their oversecurity). 
will, with some substantial likelihood, lead to inefficient continued investment.

In some situations, courts may be able to use this insight and deny ill-advised exceptions to avoidance. For example, certain preferential transfers that are otherwise voidable are exempt from avoidance if the transfers are payments in the ordinary course of business of loans incurred by the debtor and advanced by the creditor in the ordinary course of business. ${ }^{105}$ The notion behind the exception for an "ordinary" payment, like that for payment of a secured debt, is that such a payment is probably not the product of a creditor's race to a firm's assets. ${ }^{106}$ It is, of course, possible to criticize this exception, like that for payment of secured debt, by reference to this Article's analysis of investment incentives. A court that understands investment incentives in this context can do more than bemoan the exception. Such a court can deny the exception for repayment of a loan incurred while a firm is financially distressed. A court might reasonably conclude that such a loan is a product of management's overinvestment incentive and, therefore, not incurred by the debtor in the ordinary course.

Unfortunately, courts tend not to understand the nature of overinvestment and tend to feel they are serving investors when they decline to void repayments of loans made to "save" financially distressed firms. ${ }^{107}$ As the Supreme Court stated in Union Bank $v$ Wolas, without the ordinary-course exception creditors might be "reluctant to extend even short-term credit ...., thus making it difficult for many companies in temporary distress to have remained in business." ${ }^{\text {"108 }}$ What the Court overlooked is that distress may seldom be truly temporary. Any sort of distress may be a strong signal that a firm should not remain in business. Therefore, "protecting" firms by refusing to void repayments may well be inefficient.

100 See 11 USC $\$ 547(c)(2)$.

${ }^{106}$ See Union Bank $v$ Wolas, 112 S Ct 527, 532 (1991) (discussing the legislative history of $\S 547(c)(2)$ ). See also Jackson, The Logic and Limits of Bankruptcy at 131 (cited in note 1).

107 See, for example, Union Bank, $112 \mathrm{~S} \mathrm{Ct}$ at 533; In re Jeffrey Bigelow Design Group, Inc., 956 F2d 479, 487-88 (4th Cir 1992); In re Finn, 909 F2d 903, 906-08 (6th Cir 1990).

100112 S Ct 527, 531-32 (1991). 


\section{CONCLUSION}

Preference law does not clearly deter collection. Certainly, no theoretical basis exists to conclude that any deterrent effect is significant. As a result, the best justification for preference law is not that it deters collection from a static pool of assets, but that it deters an insolvent firm's investment in unduly risky projects, not least of which is continuation itself.

To be sure, such justification is not certain. Investors may be able to identify in advance those firms for which underinvestment more than overinvestment is an important insolvency problem. For this reason, it is unfortunate that the preference rules are immutable. Firms should be free to choose terms of preference avoidance, just as they are free to choose other terms of their capitalization contracts. Yet, given the prospect that a distressed firm's predominant addressable problem is a risk of overinvestment, not of underinvestment, preference law's sin of immutability may be a minor one. 